Article

\title{
Study of the Training of Environmentalists through Gamification as A University Course
}

\author{
Paz Fernández *D and Matías Ceacero-Moreno
}

Department of Civil Engineering, University of Granada, 18071 Granada, Spain; matiasceacerom@correo.ugr.es * Correspondence: pazferol@ugr.es; Tel.: +34-958-246156

\begin{abstract}
The United Nations Agenda for 2030 lists Sustainable Development Goals which include quality education, which we have pursued in the Undergraduate Final Project of the Environmental Sciences Degree at the University of Granada (Spain). This entailed designing sustainable cities, including the management of natural hazards. We created an innovative didactic model using gamification, in which the student adopted the researcher role using the computer game Cities: Skylines as a simulation tool. Using a design-based method, we conducted a qualitative single-case study in which the professor observed the process and guided the student's self-learning in a fun way. Under this guidance, the student made decisions alone in order to simulate a sustainable city, and afterwards to analyse the findings. Three variables were considered in order to evaluate the results concerning the quality of the student's learning: (1) the experiment using the game, (2) motivation, and (3) the skills acquired. In all three, the student earned a high score. Of the 12 skills established as the specific goals of the teaching plan, the student reached a very high level in 10, and a high level in two, implying the overall success of the learning process. The study achieved its main goal, as an innovative didactic methodology was established based on student's research, using gamification and simulation with a technological tool. Moreover, the case study gave positive results, with the student proving capable of developing scientific and professional competencies at an optimal level.
\end{abstract}

Citation: Fernández, P.;

Ceacero-Moreno, M. Study of the Training of Environmentalists through Gamification as A University Course. Sustainability 2021, 13, 2323. https://doi.org/10.3390/su13042323

Academic Editors: Jin Su Jeong and Adélia Nunes

Received: 15 December 2020

Accepted: 12 February 2021

Published: 20 February 2021

Publisher's Note: MDPI stays neutral with regard to jurisdictional claims in published maps and institutional affiliations.

Keywords: sustainable development goals (SDGS); simulation; gamification; higher education; natural hazards; sustainable city

\section{Introduction \\ 1.1. Object of the Study}

Environmental sustainability is the main global challenge that humanity currently faces. This goal was expressed in seventeen Sustainable Development Goals (SDGs) in the 2030 Agenda of the United Nations [1], in which one of the most important is the $4^{\text {th }}$ goal: quality education. We have worked toward this goal by training students to design sustainable cities, and to plan for-as well as manage-Natural Hazards (NH). This was carried out within the sphere of higher education in the Undergraduate Degree of Environmental Sciences offered at the University of Granada (Spain) [2].

Elsewhere [3], researchers have found that, in Spanish universities in which good teaching practices were developed with Information and Communications Technology, most of these practices refer one of the SDGs, quality education (4th). These researchers highlight this effort as the most novel: "in line with educational improvement, the SDGs are beginning to be linked to different educational areas" [1] (p. 2). With the present research, we pursue this improvement in the environmental field. The method illustrates that technology offers a tool to improve the quality and sustainability of university education worldwide.

This paper addresses a key issue of advancing in sustainability and educational quality through didactic innovation in higher education. Through gamification [4-7], we performed an experiment in relation to the university training of environmental agents, 
combining gamification with research through simulations. Specifically, we used the game Cities: Skylines (CS) [8] for the simulations, in order to design sustainable cities [9]. In this process, we built a city model that solves the sustainability challenges of today's cities in much of the world. At the same time, in the prediction and management of $\mathrm{NH}$, we achieved good results in the sustainable cities that were built [10]. Here, we present the model of the didactic methodology designed and implemented for the course's 'Final Degree Project', and we discuss its results. The general scope of this research is presented below in Figure 1.

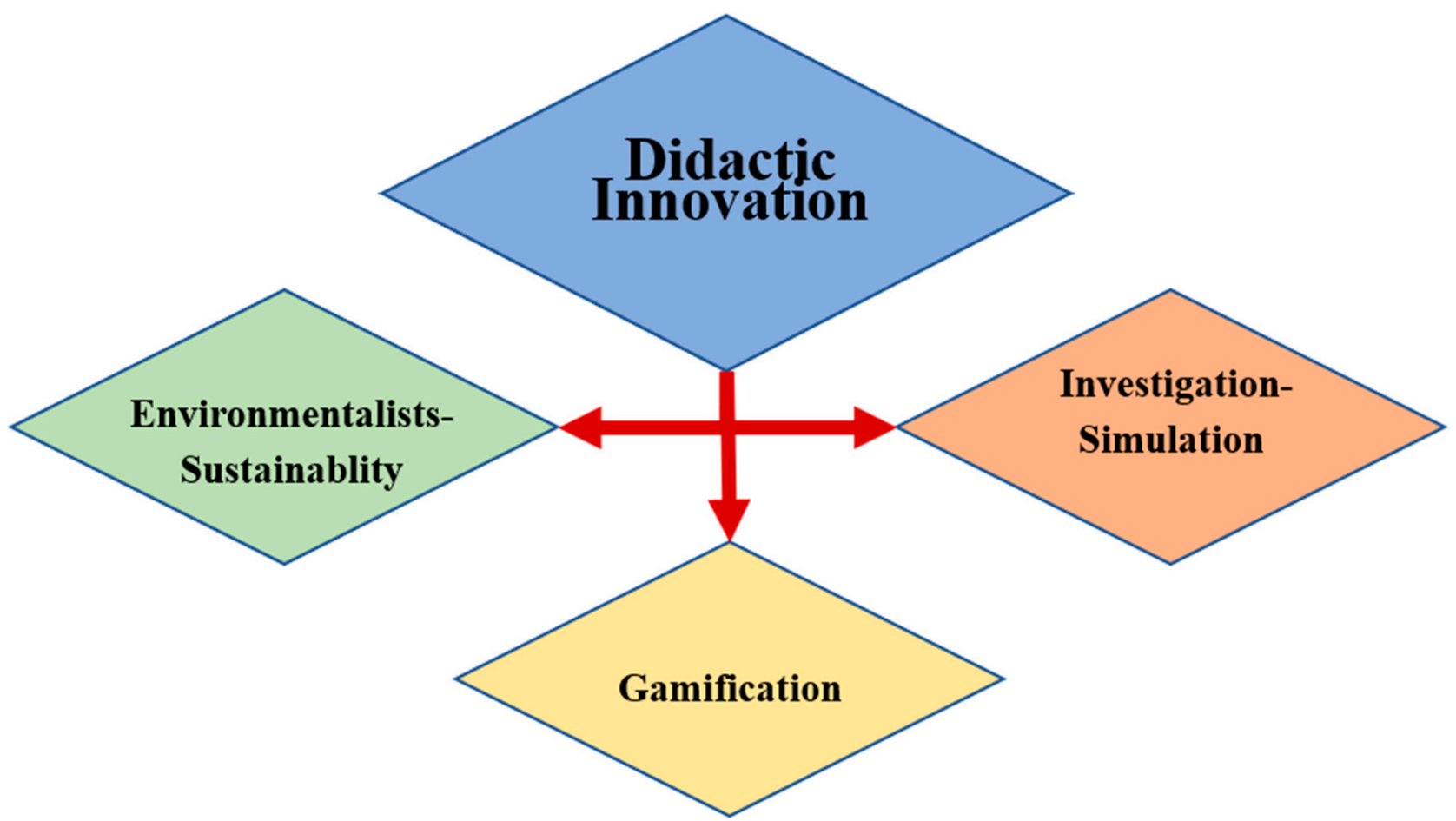

Figure 1. Didactic innovation—combining gamification and simulation—for the higher training of environmentalists in the sustainability of cities, and natural-hazard management therein (own design).

\subsection{The Research Project as $A$ Whole}

Our research project involves a complex set of investigations (Figure 2). Here, we present the second cycle of the first level of the research, making a case study of the individualized higher education of the undergraduate final project (UFP) [11]. The results of the first cycle of the first level of the research project were recently published $[9,10]$. The entire educational process, with its Blended Learning [12,13], was monitored by the professor (the first author). Acting as a guide to provide the work plan and the resources needed, the professor also offered an accompaniment. The student conducted simulations through a gamification system that also became the object of study, in order to test its validity as a means of modelling. In addition, the instructor cleared up doubts and posed questions, using the playful systems to formulate working hypotheses with which to combine prior knowledge with new findings. In this way, a novel teaching-learning process was developed which stimulated enquiry and interest in new technological resources.

The scientific goals concerning the environment are complementary to the teachinglearning priority goals of this study. Therefore, we mention the concepts of the sustainable city and $\mathrm{NH}$ succinctly in order to contextualize the research. 


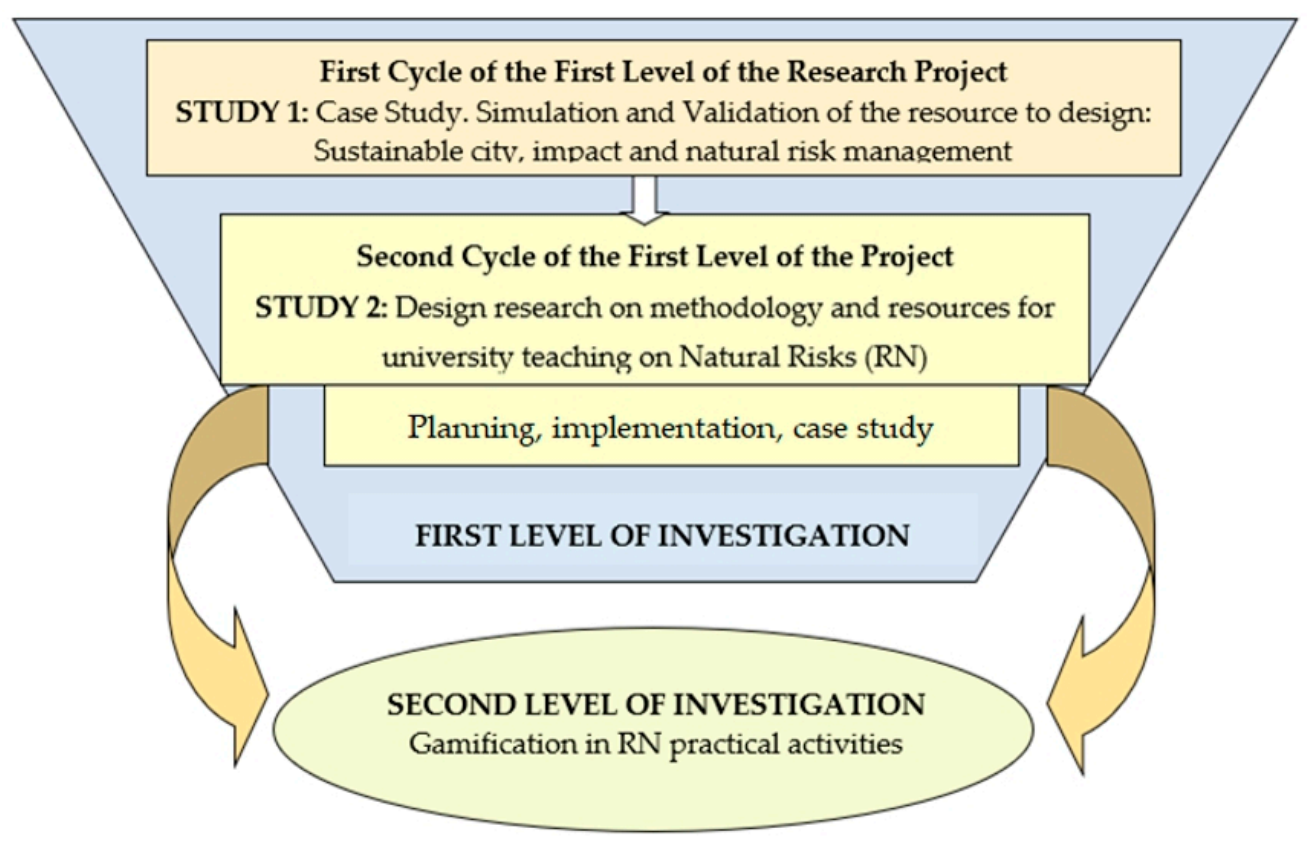

Figure 2. Research project scheme (own design).

\section{Framework}

\subsection{Natural Hazards}

In 2009, the United Nations General Assembly designated a date to commemorate the International Day for the Reduction of Natural Disasters. Later, in 2015, it established a regulation — the 'Sendai Framework for Disaster Risk Reduction 2015-2030' [14] — so that nations could address natural-risk management together. This document establishes Guiding Principles, of which we highlight the following: "States have the primary responsibility to prevent and reduce the risk of disasters, among other things through cooperation." Decision-making concerning risks should be inclusive and knowledge-based, with a multihazard approach. Furthermore, the General Assembly set goals, one being to significantly increase people's access to multi-hazard early-warning systems and disaster risk information. Four priorities were set, the fourth being to improve disaster preparedness for effective response. Operationally, a considerable increase was recommended in the availability and access to public early-warning systems for multiple hazards, along with information on disaster risk [14] (p. 37). In conclusion, they place great importance on the population being informed, and on knowing the risks and how to react to them. This implies the need to address these issues in early education and onward.

In this context, a natural hazard $(\mathrm{NH})$ can be defined as any natural process that threatens human life or property, although the process is not a hazard in itself, but rather only becomes one when it threatens human interests [15]. Furthermore, a city is sustainable if it is resilient and resistant to NH. Other authors [16] define urban resilience as the capacity of a city and its urban systems (social, economic, natural, human, technological, and physical) to absorb damage and reduce the impact of a perturbation, as well as to adapt to those changes. In this sense, urban resilience is based on four concepts: resistance, recovery, adaptation, and transformation. These, in turn, can be divided into five dimensions: natural, economic, fiscal, social, and institutional. We thus propose didactic engineering to update the teaching of engineering, and here we design a programme of didactic engineering with research through simulation using gamification.

The literature concerning education on NH issues remains scarce [17-19], prompting our research project on this subject at the university level. Our interest in educating students on the issue of NH is shared by other researchers [20] who studied the eruption of a volcano in Cape Verde, and its consequences for the population. These authors proposed a didactic application that can interconnect the size of the population with the severity of 
the risks, based on a strategy of simulation and subsequent debate. Other authors [21] have examined education in $\mathrm{NH}$ in Portugal, seeking to assess the ability of ninth-grade students to identify and classify the NH most likely to occur in that country. The results show that the students, in spatial terms, clearly define the areas most vulnerable to each of the risks listed, identifying forest fires and heat waves as the most likely to occur, both at the national level and in all municipalities in the area of Porto. They showed that analysis at the district level can help to define priorities in different areas in order to design appropriate prevention measures and improve fire prevention [17] (p. 12). This finding agrees with our study using simulations with a sustainable city modelled through gamification.

Another study [22] verified that the lack of training of the public concerning risks worsens damage and weakens prevention. These authors state that "the results suggest that community members perceive a low-risk for landslides, despite the community's location in high-risk areas. The community's perception of low risk results in a lack of preparedness and an unwillingness to relocate a comparatively safer place" [22] (p.1). Therefore, we recommend the development of special educational programmes for the general population [21].

\subsection{Gamification}

The main aim of this work is to introduce an innovative didactic methodology in the university education of environmental agents. In order to achieve this, we used gamification, applying gaming resources (designs, dynamics, elements, etc.) in non-gaming contexts in order to alter the behaviour of individuals [4]. However, the definition of gamification by Deterding et al. (2011) [7] is much more elaborate and precise, specifying that gamification refers to games, rather than to play (or fun). The definition pertains to the fields of human-computer interaction and game studies [7] (p. 9).

A major gamification study of theorisation and conceptual clarification [7] defines 'gamification' as the use of game design elements in non-game contexts [7] (p. 10). Here, we provide a synthesis of their detailed concepts. First, 'gamification' relates to games, not to play (or playfulness), where 'play' can be conceived of as a broader, looser category than 'games' [7] (p. 9).

In order to systemize the terminology, we distinguish the following:

- gamefulness (the experiential and behavioural quality);

- gameful interaction (artefacts affording that quality);

- gameful design (designing for gamefulness, typically by using game design elements).

'Gamification' usually coincides with gameful design, as defined above. The most likely strategy of designing for gameful experiences is to use game design elements, and the most likely goala of the use of game design elements are gameful experiences [7] (p. 10). However, analytically, gameful design and gamification encompass the same phenomena through different intentional properties, such as the design strategy of the use of game design elements (gamification) or the design goal of designing for gamefulness (gameful design) [7] (p. 11).

In summary: 'gamification' refers to:

- the use (rather than the extension) of

- design (rather than game-based technology or other game-related practices)

- elements (rather than full-fledged games)

- characteristic of games (rather than play or playfulness)

- in non-game contexts (regardless of the specific usage intentions, contexts, or media of implementation).

In this definition, 'gamification' contrasts with other related concepts via the two dimensions of playing/gaming and parts/whole. Games, as well as serious games, can be differentiated from 'gamification' through the parts/whole dimension. Playful design and toys can be differentiated through the playing/gaming dimension [7] (Figure 1, p. 13). The use of games in non-game contexts can be divided into full-fledged games (serious 
games) and game elements, which can be further differentiated into game technology, game practices, and game design. The latter refers to 'gamification'.

In the theory of the above authors [7], five levels in gamification can be distinguished: interface design, game design patterns or game mechanics, design principles, heuristics or lenses, conceptual models of game design units, and the design process. These are explained by these authors in a table, which we reproduce in Table 1.

Table 1. Levels of game design elements. Taken from [7] (p. 12).

\begin{tabular}{ccc}
\hline Level & Description & Example \\
\hline Game interface design patterns & $\begin{array}{c}\text { Common, successful interaction } \\
\text { design components and design } \\
\text { solutions for a known problem in a } \\
\text { context, including prototypical } \\
\text { implementations }\end{array}$ & Badge, leaderboard, level \\
Game design patterns and mechanics & $\begin{array}{c}\text { Commonly reoccurring parts of the } \\
\text { design of a game that } \\
\text { concern gameplay }\end{array}$ & $\begin{array}{c}\text { Time constraint, limited } \\
\text { resources, turns }\end{array}$ \\
\hline Game design principles and & $\begin{array}{c}\text { Evaluative guidelines to approach a } \\
\text { design problem or analyse a given } \\
\text { design solution }\end{array}$ & $\begin{array}{c}\text { Enduring play, clear goals, variety of } \\
\text { game styles }\end{array}$ \\
\hline Game models & $\begin{array}{c}\text { Conceptual models of the } \\
\text { components of games or } \\
\text { game experience }\end{array}$ & $\begin{array}{c}\text { MDA; challenge, fantasy, curiosity; } \\
\text { game design atoms; CEGE }\end{array}$ \\
\hline Game design methods & $\begin{array}{c}\text { Game design-specific practices } \\
\text { and processes }\end{array}$ & $\begin{array}{c}\text { Playtesting, playcentric design, value } \\
\text { conscious game design }\end{array}$ \\
\hline
\end{tabular}

The gamification of this study falls into level 2 (shaded). As can be seen, this 'level model' distinguishes interface design patterns from game design patterns or game mechanics. Although they relate to the shared concept of pattern languages, unlike interface design patterns, neither the game mechanics nor the game design patterns refer to (prototypical) implemented solutions. Rather, both can be implemented with many different interface elements [7] (p. 12).

Other authors [23] have stated that gamification can have several applications. It is highly developed in the business world, with the aim of guiding the behaviour of customers and employees. In governmental contexts, it can serve to attract citizen participation, as in the project Speed Camera Lottery, based on the contest for ideas to address social needs [4]. It also has uses in health to raise public awareness concerning diseases, as in the application Healthy Heart, which encourages a healthy lifestyle [24]. Recently, its use in education has expanded into different fields, such as language learning, which uses the mobile-phone app Duolingo [25]. It has advanced in the sciences, but not so much for technical knowledge, for which publications remain scant $[26,27]$.

In relation to gamification applied to the SDGs, several papers offer some background. In [28], the authors describe the implementation and evaluation of an exercise that applies international perspectives, liberal arts, and the SDGs to an engineering program of the first course. Engineering students participated in roleplaying in order to recreate the United Nations 'Conversations about Climate' of 2009 in Copenhagen. The objective was for students to broaden their understanding of the technical aspects of climate change, as well as the political and social reasons why technological solutions do not always apply. The benefits of this classroom activity include, but are not limited to, providing an experiential learning environment to understand how politics—-both personal and professional—can interact with technical solutions, leading to life improvement or disruption. Furthermore, such exercises can start a debate on the United Nations SDGs as a way to help students understand that engineering is not simply a set of problems for robotics. 
In another study, Soma et al. [29] worked on halving food waste by 2050, in line with SDG 12.3, which is key to ensuring a sustainable food system. They also conducted a review of studies on gamification. That work used a simple online educational game, based on trivialities, with facts and strategies to help the participants learn to reduce food waste. Frequent players generated less edible food waste than did infrequent players. Based on the evidence for gamification as a promising tool for educational change, we recommend further study. Goal 4 of the SDGs, Sustainable Education, indicates that all individuals should have the same opportunities to develop their skills and knowledge. Following this trend, Díaz-Lauzurica et al. [30] developed a practical experiment on how to teach computational thinking (CT), using robotics. These authors reported the results and the evaluation of the robotics lessons given to students in the $4^{\text {th }}$ year of high school, which reflected a high degree of apathy and demotivation. The teaching unit was based on an action research approach that includes a careful selection of pedagogical techniques to attract and maintain the attention of students. In addition to the robotics lessons, prior training in computational thinking was provided with Blockly Games, which significantly boosted the motivation of the students, and introduced them to the programming of the robots. In addition, gamification was used to motivate and assess individual knowledge, after which the students were asked to present their work through a final project. Due to the good results, these authors proposed the combination of different methodologies for different units, such as the flipped classroom and gamification. Other works on gamification and SDGs deal with motivating changes in water consumption, [31]. The growth of gamification in the water sector is being driven mainly by the generalization of smart meters, the use of a new generation of apps, and emerging technologies.

The University of Granada, through gamification with its 'QUODS' application [32], promotes getting started on the 2030 Agenda in a fun way. This workshop seeks to help children understand the importance of setting goals to face the world's problems and, in turn, to know the SDGs. In this educational sense, regarding the SDGs, the book [33] proposes a game to work on a number of issues (p. 76).

Several authors have discussed certain characteristics that a gamification system needs in order to be effective, and some [34] have concluded that the best way of implementing this system is through the following steps:

1. Define the aim: these authors hold that, although this may seem obvious, it is possible that it will not receive the attention it deserves, because, for gamification to be effective, an accurate comprehension of the objective is fundamental.

2. Delineate the behaviours pursued: with this, the aim is to ascertain the intention of the players, as well as to establish the method of measuring the results.

3. Describe the players: this consists of depicting and characterizing the persons who will be using this system.

4. Develop activity cycles: the idea is that the actions of the players provoke a response on the part of the game, which in turn prompts a response in the player, and so on. In this sense, two types of strategies can be differentiated: action loops (based on the motivation to accumulate points, for example) and ladder progression (based on experience gained by surpassing levels, for example).

5. Take into account the entertainment: though this depends on various factors, such as the preferences of each player, the system should be pleasant in order to guarantee its success.

6. Establish the appropriate tools: as opposed to the previous steps, this one does not consist in designing the gamified system, but rather involves the selection of the mechanics and components appropriate to our system.

In our case, we used the videogame Cities: Skylines (CS). Although this is subjective, in our opinion, the game presents entertaining and attractive mechanics that make its use enjoyable. 


\subsection{Related Works}

We have accepted the advantage of teaching by gamification and simulation, based on the literature on the subject, but we have not made an in-depth evaluation of our gamification process, which could be achieved using the Technology-Enhanced Training Effectiveness Model (TETEM). This model was adopted elsewhere [35] (p. 10). Because it evaluates experience with videogames, attitudes toward game-based learning, control valence, and gamified valence, and can be used to assess the relationship between gamification and training. Their study is the first to adopt the TETEM questionnaire to evaluate a serious game for teaching programming. The results of their survey support the claim that a gamified learning experience leads to higher valence (the anticipation of gain from learning or what is learned more and sooner). This implies a causal relationship between the use of gamification and the learning outcomes [35] (p. 13). Furthermore, Armstrong and Landers [36] (pp. 514-515) claim that TETEM describes the relationship between training technologies and training outcomes. Using the paths that this model describes, training technologies — such as gamified training — can be evaluated. Furthermore, by gamifying a training course with a single game element (e.g. game fiction), researchers can isolate and examine the effects of that element on training outcomes [36] (p. 515). TETEM incorporates the effects of individual differences and contextual variables, and their relationships with training outcomes according to updated theoretical and empirical findings. This makes it the best model through which to evaluate game fiction-enhanced training, which was the second major finding of that study [36] (p. 515).

However, the application of TETEM suggests that gamification may not change instructional outcomes when learner attitudes towards game-based learning and experience with videogames are low [37] (p. 499). In addition, for gamification to be successful, the attitudes and experience of participants must be assessed and ensured before gamification is implemented [37] (p. 499).

Games are complex systems defined by mechanics and rules, through which the players interact with that system. Elliott Avedon, in his book The Study of the Games [38], determines 10 structural elements to understand the interactions in games: the purpose of the game, the procedure for effecting the action, the rules governing the action, the number of players, the role of the players, the outcome or reward, the skills required, the patterns of interaction, the physical activity needed to play, and the equipment required. The game mechanics include any action performed by the player that modifies the game state- that is, the position and specific characteristics of all of the objects and environments of a game at a precise moment in time, due to one of the defining characteristics of games, i.e., interactivity [39].

We coincide with other researchers [17] in the proposal of the research, and partly in the methodology, as they indicate that "the purpose of this case study is to explore the principles and practices of sustainable development in the university curriculum" (p. 473). We agree with other authors [17] in striving to renew didactic methodologies in engineering and in research with the techniques chosen for compiling data: "document analysis and interviews are used as methods to compile data" [18] (p. 436). We share the interest in "hazard evaluation" expressed by previous researchers [34], who, using the Hamy Mean operator and others, propose and broaden the methods of multiple-attribute decision making with these operators, and-in order to test the methods proposed-use "an example applicable in hazard evaluation, for engineering projects of construction" [34] (p. 1536).

It is necessary to develop the technical training of today's university students, as stated by other researchers [40], who indicate that:

... in the current normative context in Spain, the law on educational quality and improvement (Ley Orgánica de Mejora de la Calidad Educativa) includes different references in this sense. The power of information and communications technology TIC as a motor of methodological change becomes accentuated, as does the impact that it may have on 
the way that students learn, on their manner of communicating, and on their methods of facing new tasks and challenges [40] (p. 61).

With our research, we seek such a development.

In an international context, some authors have applied gamification structure and roles in technical education in universities. In one study [41] the authors developed a tool for learning and robotics competences by means of online games, including a complete course to program drones in engineering education. Other authors [42] proposes a strategy to improve the motivation of the students studying software engineering in less attractive but important areas of this matter. Motivation is also the main objective of another work on gamification [43], as implemented in studies in physics. Elsewhere [44], this key question was considered in the learning of statistics. These authors conclude that their challenge-based gamification experiments gave positive results in the students learning in comparison with traditional methods. As a counterpoint, other researchers [45] consider motivation by gamification in their experiment, but they contend that it is vital to ensure that the game rules are clear, that the elements make sense, and that there is ample educational feedback.

\section{Objectives}

The overall aim of the present study is to design and implement an innovative university course, with gamification as a didactic methodology, and $\mathrm{NH}$ research through simulations as the content. The specific objectives of the study are: (1) to design the course, developing the goals of the course, its contents, the necessary material resources, the programming of the student activities, and a temporary schedule; and (2) to plan the implementation of this course, establishing a didactic methodology and a context in which to develop it.

\section{Method and Materials}

\subsection{Method of the Investigation}

This research fits within that dealing with design [46-49], focusing on university education through the application of gamification to guided research and scientific simulations. Design-based research (DBR) is defined as a type of research aimed at educational innovation, of which the fundamental characteristic consists in introducing a new element to transform a situation [50] (p. 1). These studies arose with Brown (1992) and Collins (1992), who emphasized the production of knowledge, with the ultimate goal of improving the educational design, development, and evaluation processes [51]. However, its roots are in the field of Engineering and other applied sciences. Similarly to action research, design-based research deals with real problems that are identified by practitioners in their activities [52]. Throughout our study, this methodology (DBR) was used. According to other sources [51], [53], the "main characteristics are: i) the decision to place the research in the natural context; ii) the purpose of causing specific changes in this context; iii) The systemic approach to problems; and iv) the cyclical and repetitive nature of the designs" [53] (p. 2). Likewise, "it seeks to understand and improve the educational experience through the consideration of natural contexts in all their complexity, and the development and parallel analysis of a specific instructional design" [54] (p. 75). In our study, both the professor and the student acted as a researcher through roleplaying in gamification. The researchers became an integral part of the investigated system, interacting with it, leading to complex relationships that broke the conventional distinction between researcher, professor, and student. In general, we expected the student to build knowledge about a topic, and the professor to build knowledge about ways of learning, and about the interactions between the student and the game. Due to this distinction of different planes of action, these studies are sometimes called 'multilevel' or 'multistage' [52] (p. 79), and are complex to describe.

Next, we show an initial cycle of this research, using gamification and research with simulations, in the context of university education. In general, as mentioned above, we worked at two levels: the first level addressed the improvement of teaching in engineering, 
establishing a model to prepare and develop the Undergraduate Final Project (UFP), through a case study of a UFP, while the second level entailed the descriptive study of the application of the findings of the first level to the design and implementation of the practical courses on 'Natural Hazards'. The reliability of a certain technological instrument to make simulations, and the viability of the didactic methodology based on gamification (the object of this paper) were studied at the first level, and the entire process-as well as its conceptualization - can be characterized as 'didactic engineering' and design research in the same act of research and university teaching.

The case study was undertaken using techniques of observation and unstructured interviews, compiling the data with reflection and interpretation. This was supported by the following tools: the professor's diary, and a progressive written draft of the UFP prepared by the student and presented in the discussion sessions between the two.

We qualitatively evaluated the student's competences, also using Bloom's taxonomy [55]. This taxonomy was revised in 1965 [56] and later restructured in 2001 [57]. This taxonomy of learning objectives has become a key tool in structuring and understanding the learning process. Bloom proposed that learning fits into one of three psychological domains: The Cognitive domain, i.e., the processing of information, knowledge and mental skills; the Affective domain, i.e., emotions, attitudes, and feelings; and the Psychomotor domain, i.e., manipulative, manual or physical skills. In the 2001 revised edition of Bloom's taxonomy, the levels have slightly different names, and the order differs: Remember, Understand, Apply, Analyze, Evaluate, and Create [58]. It was used from the constructivist perspective by other researchers [59] to analyse knowledge concerning information as an important topic. Information communication and collaboration or teamwork are key skills in the 21st century, as collecting and understanding available information is not useful unless the findings can be effectively communicated to the rest of the team [60]. These new skills have been added to the digital adaptation of Bloom's taxonomy that was developed recently [61], providing an updated taxonomy with new verbs and tools from the digital world that allow digital skills to be characterized at the six levels.

The final evaluations were made by the official protocols used by the members of the UFP evaluation jury, to which the professor did not belong. One of its parts bears similarities to Case 6: the organization and management of online tutoring for the management of research projects, with the objective of designing and developing a procedure for the tutoring of online research projects. This was carried out in order to offer solutions in the practice and identification the organizational and procedural elements for this endeavour [35] (p. 55). The viability of the didactic methodology, based on gamification, as well as the entire process of its conceptualization and implementation, which is the object of the present work, can be characterized as 'didactic engineering' and research DBR.

\subsection{Method of the Didactic Actuations}

Our interest was the strategy of the use of game design elements (gamification) [7] in order to improve teaching-learning at the university, developing a didactic methodology using gamification located at level 2 (shaded in Table 1). In order to implement this, we used "playful interaction (artefacts that give it that quality)" [7] (p. 11), employing the CS game, to which we have added an investigative objective, thus making it a serious game.

In order to motivate the student when performing a task, we included motivation techniques based on the psychological theories of motivation [62-68]. Table 2, below, shows the relationship between six of the most relevant theories of motivation and the most common game mechanics. Because we especially value intrinsic motivation, we sought to motivate the student by bringing together the following elements in gamification (which was adopted as a didactic method): the mechanics of missions or challenges, levels, prizes, and classifications. These were applied in the context of the research tasks developed by the student, with the serious CS game as a tool. The missions or challenges consisted of facing the difficulties involved in assuming the role of researcher, which was a specific challenge posed by the gamification methodology. 
Table 2. Theories of motivation related to game mechanics (Source: [69]).

\begin{tabular}{|c|c|c|}
\hline Theories of Motivation & Game Mechanics & Significate \\
\hline $\begin{array}{l}\text { Maslow's theory of the hierarchy of needs (1954) } \\
\text { [62]: 1-survival, 2-security, 3-social, } \\
\text { 4-esteem or status, 5-self-realization. All the } \\
\text { mechanics are related. }\end{array}$ & 1. Points & Assign a quantitative value to an action \\
\hline $\begin{array}{l}\text { Dual factor theory of Herzberg, Mausner and } \\
\text { Snyderman, (1967) [63]. Hygienic factors: They } \\
\text { are external; Motivational factors: They refer to } \\
\text { the work-game itself. All the mechanics are } \\
\text { related to these. }\end{array}$ & 2. Levels & Thresholds that are met by accumulating points \\
\hline $\begin{array}{l}\text { McClelland's theory (1989) [64]. Three types of } \\
\text { motivation: Achievement: points, levels, } \\
\text { challenges, missions or challenges. Power: } \\
\text { rankings, points, levels, virtual goods, gifts. } \\
\text { Affiliation: levels, gifts, points. }\end{array}$ & 3. Awards & $\begin{array}{l}\text { Physical or virtual accreditation that a goal } \\
\text { was achieved. }\end{array}$ \\
\hline $\begin{array}{l}\text { Theory of Expectations. Vroom, (1964) [65], } \\
\text { completed by Porter and Lawler, (1968) [66]. } \\
\text { Motivational strength combines: Probability of } \\
\text { achievement and value of reward. Points; levels; } \\
\text { missions or challenges; virtual goods; rewards. }\end{array}$ & 4. Virtual assets & Virtual items to express individuality \\
\hline $\begin{array}{l}\text { Locke's Theory of Goal Setting, (1969) [67]. } \\
\text { Challenges, missions or challenges should be: } \\
\text { difficult, but possible to achieve. Points, levels, } \\
\text { etc. give feedback that is needed. }\end{array}$ & 5. Classifications & Assign positions in comparison to other players \\
\hline \multirow{3}{*}{$\begin{array}{l}\text { Mihaly Csikszentmihalyi's Theory of Flow or } \\
\text { Optimal Experience (1975) [68]. In order to reach } \\
\text { a state of Flow, there must be a balance between } \\
\text { the challenge of the task and the skill of the } \\
\text { player. All the mechanics. }\end{array}$} & 6. Challenges & $\begin{array}{l}\text { Competition among the community or between } \\
\text { different opponents }\end{array}$ \\
\hline & 7. Missions or challenges & Tackling a specific challenge posed by the game \\
\hline & 8. Gifts & $\begin{array}{l}\text { Offering free goods to the player or } \\
\text { between players }\end{array}$ \\
\hline
\end{tabular}

The Levels were the thresholds that are met by overcoming each of the programmed phases of the research process that the student developed and conceptualized in the roleplaying game (Figure 3).

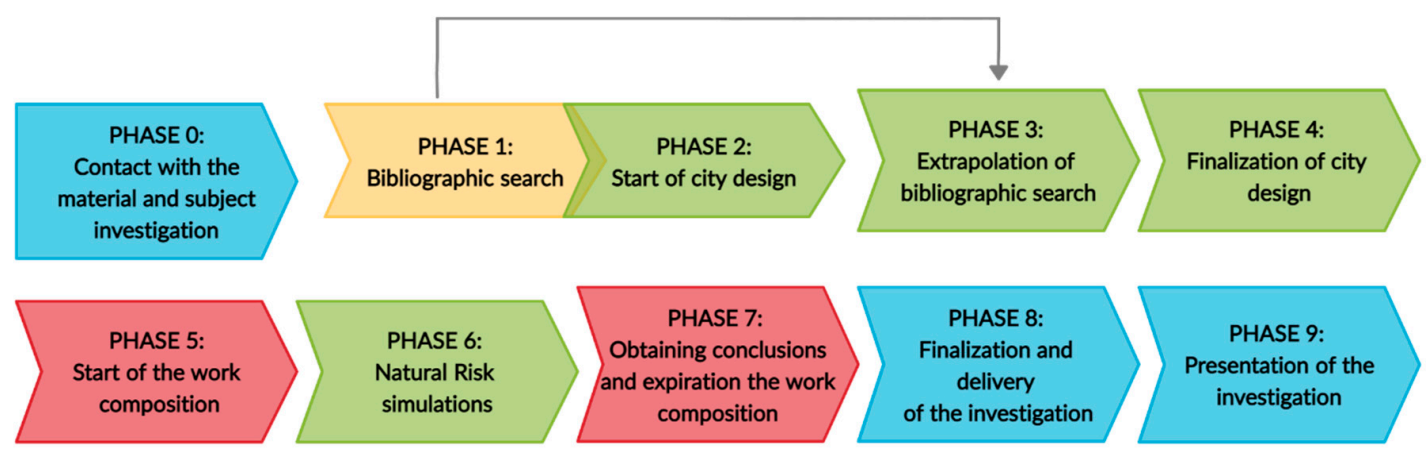

Figure 3. Sequential representation of the phases of the study (own design [9]).

The rewards were intrinsic, being related to the objectives of the CS game. That is, mastering the game generated internal satisfaction, which was motivating [63], as was also credited by the professor. This involved the concept of classifications, when assigning positions to the student, in comparison to the didactic objective and the prototypes established by the experience in this course. The student was told that his work (researching) was valuable, and that by the very action of conducting the research (regardless of the success of the effort) he rose above other classmates whose final degree project was of a different type (compilation, the application of techniques, etc.).

We studied the development of the specific and transversal competences typical of the university degree in Environmental Sciences (at the University of Granada) through didactic innovation. For this, a training and research process was designed on two levels, the first referring to the final project to be executed for the degree, this being the UFP [11]. 
In this curricular work, we proposed a personalized training process for a single case, with the completion of a course in which the subject would learn through research carried out by himself, through gamification. In this scenario, the student assumed the role of researcher, and faced a research problem that must be solved through the sequence of actions characteristic of a researcher's work. The student was supported by an experienced researcher in the role of the course professor. This was designed and implemented by combining class attendance with online learning, in which self-study based on guided enquiry alternated with enquiry tasks and discussions with between the professor and a single student. This involved the learning method with mixed or blended attendance that we have previously established [13]. This training process is exemplified with a case study, focused on the research problem of building a sustainable city model through simulation with a game, in which natural risks and their prevention were studied [7]. The second level of the training process refers to the subject matter of the degree, which is called 'Natural Hazards', in which the findings of the first level are applied to formulate practical tasks. This process is vital because the phenomena that are studied in practical training cannot, by their nature, be artificially replicated, so it is necessary to have a technological simulation instrument that is reliable and accessible to students. The reliability of such an instrument is studied at the first level through simulation, and the entire process-as well as its conceptualization-can be characterized as 'didactic engineering' and 'design research' in the act of university teaching.

To describe the model of blended-attendance methodology designed specifically for this case, we used the phase diagram of Figure 3, drawn independently by the student of the case study in Phase 7 (showing a high level of metacognition in the process of the student's own learning, which can be considered another result of the study). Phases 0 , 1,8 , and 9 of the diagram in Figure 3 were undertaken during physical attendance (one part was personal attendance, and the other part was online) and strictly following the instructions of the professor. The green phases $(2,3,4$, and 6$)$ were the most independent for the student, who acted following the instructions of the professor, but in a modality of 'independent work'; the student made decisions independently and without personal attendance. Phases 5 and 7 were without attendance, but with greater online interaction with the professor, making consensual decisions. The entire implementation process took place between October 2019 and July 2020, which-in the first quarter of the school yearproceeded normally, with alternating two-week sessions of attendance with independent work periods directed by the professor. From March 2020, the process took place online with periodic online consultations (at the request of the student) in a context of uncertainty and social upheaval due to the Covid-19 crisis. This led to a greater use of the technologies for didactic communication and orientation, reflecting the usefulness of the information and communications technologies, as well as the appropriateness of the blended-attendance design in these times.

Our gaming process includes the steps established elsewhere [54], described as follows:

1. Define the objective: place the student in the role of researcher to make simulations of a sustainable city.

2. Delineate the intended behaviour of the player: in order to understand and practice the selected game, establish the method of measuring the results. If all of the requirements of the simulations are properly followed and a model of the city results, the student will have won the game.

3. Describe the players: the people using this system will be students in the last year of their undergraduate work.

4. Develop cycles of activity: each of the progressive levels of the game itself will culminate in a city model, which suitable or not for sustainability. It is not a strategy of action loops (based on the motivation to accumulate points) but rather a strategy of staircase progression (based on the overcoming of levels, which is achieved by accumulating inhabitants and obtaining a bigger and more complete city). By overcoming these levels, the player earns several rewards, such as more land for 
the city or new services, which will increase the functionality of the game and the player's motivation).

5. Keep the game pleasant, and do not change its pace for learning purposes.

6. Establish the appropriate tools, unlike in the previous steps: this does not consist of designing the gamified system, but rather involves the selection of mechanics and components appropriate to our system, which we accomplished by taking the videogame mentioned, $\mathrm{CS}$, the mechanics of which we explain in the Materials section. In order to evaluate all of these actions, we used the theory of didactic models [70], as described below.

\subsection{Didactic Method for Results Evaluation: Competences}

The didactic objectives (OD) of our research were:

General Objective: for the student to self-manage the learning tasks related to the three focuses of interest, which were research, gamification, and sustainability in relation to NH. This was intended to promote, as specific objectives, the following competencies, selected from the academic curriculum of the Degree in Environment at the University of Granada (using their respective numeration).

Specific objectives:

OD1 General competences:

1. Cutting-edge knowledge;

2. Apply the knowledge to problem solving;

3. Gather and interpret data, reflect and make judgments;

4. Transmit information;

5. Learning autonomy.

OD2 Transversal (CT) and Specific (CE) competences:

CT1 Understanding the scientific method. The ability to analyse synthesis, and problem solving.

CE8 Analyse and interpret meteorological, climatic, and hydrological processes.

CE11 Handling and application of a Geographical Information System, and the interpretation of remote sensing images for environmental purposes.

CE12 Sample design, data processing, the interpretation of statistical results, and statistical programs and databases.

CE16 The knowledge and appreciation of data sources and techniques for the territorial analysis for sustainability;

CE35 Integrated planning and management of the territory.

CE36 The knowledge of the processes related to natural and technological risks, and the development of mitigation and risk prevention plans.

Of these, we associate 2, 3, CT1, and CE12 with the research process, and 1, 4, and 5 with learning and gamification as the didactic method, and also with CE8, CE11, CE16, CE35, and CE36, which relate to the specific content of $\mathrm{NH}$, and which constitute the scientific-technological content of the didactic programme. Finally, the key aim of this study is for the student, independently, to handle the interactions between the three focuses (research, gamification, and NH sustainability). This was carried out by the first author acting as the professor, with the second author acting as a student finishing the undergraduate degree. The latter is the co-author of the publication, thus providing evidence of the high level achieved in this key objective.

\subsection{Materials}

Similar to the game we have selected for educational purposes, the SimCity Game was used in a different study [71] (p. 6) as the independent variable, with spatial intelligence as the dependent variable, and with location, distance, direction, and relief as indicators. Compared to conventional media, SimCity was found to improve learners' spatial abilities. Meanwhile, Pramaputri and Gamal [72] show that there was a great deal of academic discourse on the kinds of competence that can result from the use of simulation. The 
result of that paper shows that several types of simulation can serve to train specific spatial competencies in students [72] (p. 1). Interactive simulations-such as Sim Life or SimCity-have been used for instruction, ranging from biology courses at the collegelevel to city planning, respectively, but usually at the college level and above [72] (p. 6). Other authors [73] have studied the benefits of engaging students using virtual, interactive systems, as opposed to a passive presentation model, at any educational level.

Another study [74] describes the use of SimCity in the university course Infrastructure Management, methodologically observing students' motivations, the didactic scenario, and the perceived learning outcomes. The results show that SimCity 4 can still serve as a platform for exciting learning scenarios more than 15 years after its initial release; it could also be shown that the didactic scenario motivates the students, and that SimCity also generates gaming fun [74] (p. 1). Another study [75] holds that simulation videogames (SVGs), an extremely wide category of modern videogames, provide innovative educational possibilities for personal and professional development because they represent practically all forms of human activities, which in turn may raise sophisticated ethical issues. For example, construction and management SVGs raise moral dilemmas in city management (Sim City) [75] (p. 705). Thus the findings of the paper may be useful in game-based learning and modern ethical research [75].

In line with the above studies, we used the videogame Cities:Skylines (CS), which has previously been used for educational and territorial planning purposes [76]. We used it as an instrument within gamification, for university training on the subject of the Analysis and Management of Natural Hazards. Several authors have written about its various uses, such as the simulation and visualization of real cities [77]. Other authors [76] have analysed its educational potential for training in land-use management, concluding that this game has advantages and disadvantages compared to others, such as serving as a territorial planning tool. Based on this evaluation, we chose the game as a simulation tool for this research on $\mathrm{NH}$ in a city, since it permits the building of approximate models which, although simplified, represent reality. Its shortcomings are clearly perceptible, and thus can be taken into account in a teaching-learning process at the university level.

Taking advantage of the mechanics of this game, we have added the learning objective, making it a serious game. CS is based on the construction of cities [78]; in the game, the player acts as the mayor of the city, who must design the community, establishing the road networks, the energy sources, and the water collection and purification systems, etc. In addition, services such as education, health, and safety must be provided for the population. In the role of mayor, the player must also manage the finances of the city, and must follow legislation in all facets.

The game is structured into several levels depending on the number of inhabitants, as this is based on the development of the city to reach the maximum population possible. The game starts with a village, with 500 inhabitants, and will expand through other intermediate levels such as a city $(16,000$ inhabitants) and a capital (30,000 inhabitants), until reaching the last level, a megapolis (75,000 inhabitants). By overcoming these levels, the player will earn several rewards which will increase the functionality of the game, such as a greater area of land for the city, or new services such as new public transport, new energy sources, or new laws. In order to achieve a greater population, and to be able to surpass a level, the player must define, based on the demand, larger residential, commercial, office and industrial zones, establishing services such as electricity, water, garbage collection, and safety. The game provides an information panel for the city, offering information both on its status and on availability, use, and size, depending on the section.

These sections are quite complete in their information: electricity, water, garbage collection, education, happiness (showing the level), health, wind, traffic, pollution (showing the levels of soil, water, and noise pollution), fire departments (showing the coverage, as well as the local fire risk), crime, transportation, population (showing population, birth and death rates, as well as employment), land value, natural resources, districts, leisure, evacuation routes, radio coverage (showing the signal strength of some disaster-detection 
methods), destruction (showing the degree of destruction caused by some process), disaster detection (showing coverage for earthquake detection), traffic routes, tourism, guided tours, and park maintenance. All of this information is applicable to our aim. The diagram in Figure 4 makes it easier to understand the dynamics of the game.

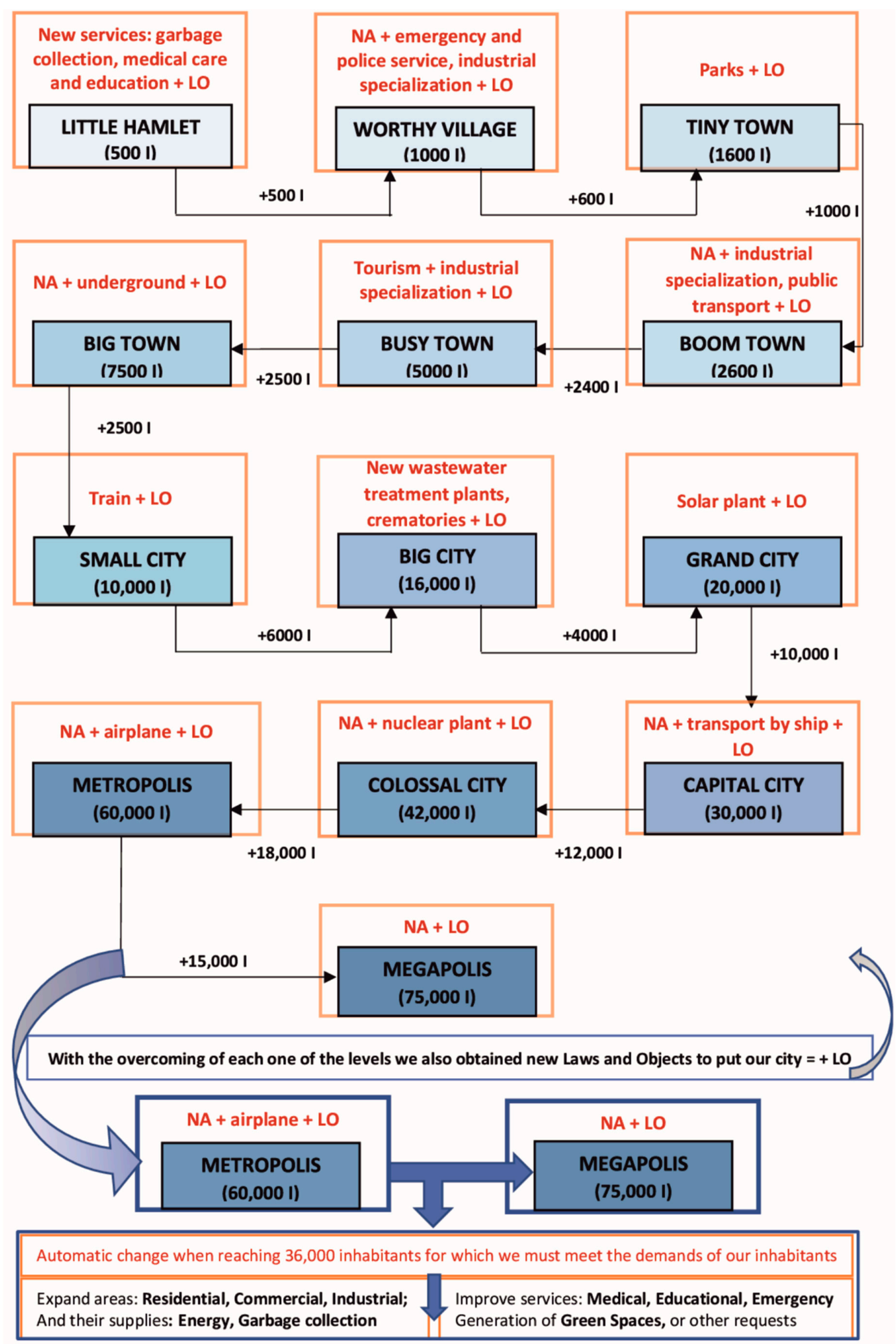

Figure 4. Flowchart of the game mechanics. Inhabitants $=\mathrm{I}$, New areas = NA, Laws and Objects $=$ LO. 
In order to evaluate the game (by the players' consultancy procedure), the student using it was asked his opinion regarding the attractiveness of the game. He responded that the game offered entertaining and attractive mechanics that made its use pleasant. For didactic purposes, the university also has an internet network, a specialized library, and a toy library at the student's disposal.

\section{Results}

\subsection{Didactic Context Underlying the Innovation Process}

The didactic system of the present study consisted of particular elements, roles, and relations. The participants were the professor, who tutored a student working on the final project for an undergraduate degree in Environmental Sciences at the University of Granada, Spain. The lecturer's aim was to teach with an innovative, engaging method for effective self-learning, so that the student would wish to learn in a satisfactory and fun way. For this, the professor designed a project combining teaching and research.

For the learning process, the professor planned a system of gamification that the student was to complement, taking on the role of a researcher, using simulations, searching the literature, and analysing the results of the simulations to compile the material to learn. This included the sustainability of cities and natural hazards $(\mathrm{NH})$, using a training process based on guided self-learning, with a videogame as a tool. The professor and the student interacted in a model of semi-attendance learning, until all of the meetings finally became electronic due to the Covid-19 pandemic, using video conference or e-mail.

The research involved a qualitative single-case study, in which the professor observed the process, took notes, made audio recordings, and analysed and corrected these and the documents written by the student. Meanwhile, the student followed the directions of the professor and made decisions alone in order to conduct the simulations of a sustainable city, and afterwards to analyse the results of the simulations made.

The resources for this process were bibliographical and technological (computer, databases, and the game). The game was chosen by the professor to be transformed into a serious game by adding the objectives required for the city to be sustainable and resilient to NH. The innovative results included the way of learning, the theoretic framework constructed using sustainable cities and natural hazards, the adaptation of the game, and the data provided by the simulations, which were not found previously, and have become an object of learning. Furthermore, the approach was designed based on the prior studies and the state of the art, examining other studies and teaching experiments similar to ours, making comparisons, and evaluating the validity and sphere of application of the findings.

The results presented here form part of a teaching experiment that was planned, developed, and analysed as a case study on the university teaching of environmentalists, including the design of the simulation [18,50]. Another work [79] stated that the main advantages of using serious games in teaching include the possibility of broadening and deepening the knowledge acquired by the participants through problem solving and decision making in real time, without risking key resources, while giving the participants more confidence to make critical decisions in the future. The professor in this study chose a commercial game and transformed it into a serious game, in part to stimulate the student's self-confidence for enquiry using simulations. Thus, these simulations were made in a context of enquiry in which the professor and student modified their respective roles and relations. The student progressively self-managed the learning, while the professor guided the student's research through simulations, offering suggestions but allowing the student to make the decisions.

The description of the above process brings out certain questions or meta-questions, such as: What was done? What were the results? How was it done? Why was it done? The latter two questions are key in interpretive qualitative research, in which the pursuits and aims of the researcher and the ways of undertaking the actions to achieve these objectives constitute a major concern. This part should be conveyed together with the results of what was done, as it forms part of them. The detailed responses to these 
questions exceed the scope of the present paper, and will be completed in another study. We summarize the detailed answers to these questions in Table 3, as they contextualize the other results presented:

Table 3. Questions about the didactic context of the study.

\begin{tabular}{|c|c|c|}
\hline \multicolumn{3}{|c|}{ Meta-Questions of the Case Study on the University Training of Environmentalists } \\
\hline \multicolumn{2}{|c|}{ Regarding the 4th SDGs: Quality Education } & \multirow{2}{*}{\begin{tabular}{l}
\multicolumn{1}{c}{ Regarding Sustainability } \\
A model for city sustainability was \\
designed.
\end{tabular}} \\
\hline What was done? & $\begin{array}{l}\text { A higher-education training method } \\
\text { was designed for environmentalists. }\end{array}$ & \\
\hline How was it done? & $\begin{array}{l}\text { With gamification, a role was } \\
\text { designed where a student was the } \\
\text { researcher and undertook } \\
\text { bibliographical searches of theory, } \\
\text { simulated experiments, made } \\
\text { decisions, conducted analyses, and } \\
\text { reported the results. }\end{array}$ & $\begin{array}{l}\text { The student adapted a simulation } \\
\text { game to the objectives of the scientific } \\
\text { matter being taught }(\mathrm{NH})\end{array}$ \\
\hline Why was it done that way? & $\begin{array}{l}\text { This was part of an effort by the } \\
\text { professor to improve university } \\
\text { teaching by didactic innovation, } \\
\text { introducing a methodology that } \\
\text { bolsters the skills of professionals. }\end{array}$ & $\begin{array}{l}\text { A virtual approach was used due to } \\
\text { the impossibility of intervening in } \\
\text { real cities to apply NH in an } \\
\text { evaluation of their effects on city } \\
\text { sustainability and } \\
\text { forecasting hazards. }\end{array}$ \\
\hline What were the results? & $\begin{array}{l}\text { 1. The training of the student proved } \\
\text { excellent in terms of technological } \\
\text { competence, specific subject matters, } \\
\text { and in self-learning. This was } \\
\text { demonstrated by the evaluation by a } \\
\text { university board and by the } \\
\text { professor, whereupon the student } \\
\text { earned the highest score. } \\
\text { 2. The usefulness of the didactic } \\
\text { method was confirmed in this case. }\end{array}$ & $\begin{array}{l}\text { 1. The experiment validated a game } \\
\text { as a valid tool to make models of a } \\
\text { city in which to study sustainability } \\
\text { against NH. } \\
\text { 2. A model of city sustainability was } \\
\text { developed. } \\
\text { 3. Having fun was shown to be } \\
\text { compatible with learning science. }\end{array}$ \\
\hline What remains to be achieved? & $\begin{array}{l}\text { The conditions of replicating the } \\
\text { method for other cases remain to be } \\
\text { established. Applications of the game } \\
\text { used for developing practical } \\
\text { learning tasks regarding NH remain } \\
\text { to be designed. }\end{array}$ & $\begin{array}{l}100 \% \text { effectiveness of the game } \\
\text { remains to be reached on simulating } \\
\text { the effects of the NH in the city. } \\
\text { Further means are needed to } \\
\text { optimize its efficiency. }\end{array}$ \\
\hline
\end{tabular}

In the present work, three variables were considered in order to evaluate the results concerning the quality of the student's learning: (1) the experiment used with the game, (2) motivation, and (3) skills acquired. In all three, the student earned high scores.

With respect to the process followed, the simulation was implemented based on one of the options offered by the game, in which the player can construct the city without overcoming levels. This proved to be more practical with the objectives set out in the work: to construct a sustainable city, and to simulate natural hazards. In terms of the approach, the player began by following the advice provided in the game (positioning roads, buildings, and sanitation services), but the design being followed did not correspond to that found in the literature, and therefore a new model of the city was begun based on previous works, until it was confirmed that the city was sustainable (effective health services, waste treatment, education, energy provision, etc.). Finally, two games were saved, one with preventive measures and the other without, and, for both, different simulations were carried out. 
With this, the player first learned about the design and management of the cities (since we also established the budgets for the design and the legislation to govern the city). Likewise, the player learned to formulate hypotheses (since we assumed that the simulation could constitute a tool in the analysis and management of $\mathrm{NH}$ ) and to work with several variables (in this case, the sustainable city itself and the means established to mitigate the effects of different phenomena). Finally, the student delved into the technology of the game, for example, by learning the limitations in terms of construction and sustainability of cities, and by perceiving aspects to improve in terms of the occurrence of natural phenomena (e.g. landslides, which are not included in the game).

Considered as a research result, an evaluation was made of the didactic method according to the didactic models theory, which affirms that "the teaching progress consists of the growing domain of the teaching models variety and the capacity to use them efficiently" [70] (p. 19). These authors establish the following as structural elements of a teaching model: the syntaxis, social system, reaction principles, and support system. We evaluated each of these elements in the method that we designed and implemented. We confirmed that the syntaxis or phase flux describing the action model was consistent with the objectives, was well defined, and was recognised by the student (Figure 3). The interactions of the professor and student roles (Table 3) constituted an open system (consensual tasks, not imposed) designed to encourage intellectual independence and positive emotions. These features promoted the learning process. The reaction principles that include the teacher's response to the student's actions, including the evaluation, were less directive because the criteria were not rigidly imposed. This fostered creativity and rewarded certain actions (decision making in the simulations, instrument evaluation of the CS) and not others (achieving a sustainable city, non-formative use of the simulations), encouraging learning from trial and error while making the student value the investigative spirit above the results. The support system (material, human, and economic) needed for the implementation of the model proved satisfactory, with sufficient bibliographic, technologic, and ludic elements. In personal terms, this required time and emotional dedication from both the professor and the student. The professor sought to stimulate the student's search for the truth, and to dispel any feeling of failure; the student, meanwhile, tried to honour the commitment to the agreed tasks. The course approach was complex, global, and multidisciplinary, with the great confidence of the professor in the objectives and actions, since the institutional system tends to be static, and fails to stimulate or reward risky innovative changes. All of these factors led us to characterize the didactic model as mixed, with the capacity to develop information processing, together with the development of personalized social interaction and situated-cognition in a technological context.

\subsection{The Results of the Study, Referred to as the 'Case Study'}

The results of study, referred to as the 'case study', are of two types: A) of the product produced, i.e., of the UFP; and B) of the student, in his role as researcher, exercised when undertaking the UFP.

The UFP was qualified quantitatively and qualitatively, by the professor and by an evaluation commission, with the highest mark given in the final evaluation. Regarding the research skills achieved by the student, the professor stated that the development of the UFP endowed the student with a high level of the following: (1) constancy in work, (2) organization in the management of the time and resources available, (3) the ability to generate a hypothesis, (4) analytical ability, (5) rigour in the process of preparing and presenting results, and (6) the student's metacognition about his own scientific and learning activity.

Meanwhile, in the specific and transversal competences achieved, the results are expressed in a rubric for the evaluation of the skills of the student (Table 4). 
Table 4. Evaluation table of the skills of the subject of the case study.

\begin{tabular}{|c|c|c|c|}
\hline \multirow{2}{*}{ Competences: } & \multicolumn{3}{|c|}{ Level } \\
\hline & $\mathrm{C}$ & B & A \\
\hline \multicolumn{4}{|l|}{ Generals } \\
\hline 1. Cutting-edge knowledge & & $\mathrm{X}$ & \\
\hline 2. Application of knowledge to problem solving & & & $\mathrm{X}$ \\
\hline 3. Gather and interpret data, reflect and make judgments & & & $\mathrm{X}$ \\
\hline 4. Transmit information & & & $\mathrm{X}$ \\
\hline 5. Learning autonomy & & & $\mathrm{X}$ \\
\hline \multicolumn{4}{|l|}{ Transversal (CT) and Specific (CE) } \\
\hline $\begin{array}{l}\text { CT1. Understanding the scientific method and ability for } \\
\text { analysis, synthesis, and problem solving }\end{array}$ & & & $x$ \\
\hline $\begin{array}{l}\text { CE8. Analysing and interpreting meteorological, climatic, and } \\
\text { hydrological processes }\end{array}$ & & & $\mathrm{X}$ \\
\hline $\begin{array}{l}\text { CE11. Handling and applying the Geographical Information } \\
\text { System and interpreting remote sensing images }\end{array}$ & & $X$ & \\
\hline $\begin{array}{l}\text { CE12. Sample design, data processing and interpretation of } \\
\text { statistical results and statistical programs and databases }\end{array}$ & & & $x$ \\
\hline $\begin{array}{l}\text { CE16. Knowledge and appreciation of data sources and } \\
\text { techniques for territorial analysis for sustainability }\end{array}$ & & & $x$ \\
\hline $\begin{array}{l}\text { CE35. Knowledge and appreciation of integrated city } \\
\text { planning and management }\end{array}$ & & & $\mathrm{X}$ \\
\hline $\begin{array}{l}\text { CE36. Knowledge of the processes related to natural and } \\
\text { technological risks and development of mitigation and } \\
\text { risk-prevention plans }\end{array}$ & & & $x$ \\
\hline TOTAL & & 2 & 10 \\
\hline
\end{tabular}

A total of 12 skills were taken as the specific goals of the teaching plan, as they have a relation to the subject matter and goals of the UFP; of these, $10(83 \%)$ were manifested by the student at a very high level, and two were manifested at a high level, implying the success of the learning process.

We adopted the taxonomic hierarchy of Bloom in the part related to the cognitive domain, as a qualitative instrument for the evaluation of the competences of the student who was the subject of the case. In the Table 5, we present the results of this evaluation.

Although it could be argued that some of the stages are not necessary for all of the tasks, actions or processes according to some experts [61], we adhere to Bloom's original idea that they are inclusive, and that each level requires the mastery of the previous level. Therefore, only three of the 12 competencies developed in the learning process were considered not to have achieved the levels of maximum creativity, i.e., 5 or 6 (evaluation or creation). This indicates some $75 \%$ achievement of the highest level, on the scale of Bloom's Taxonomy, as restructured by Anderson (2001), signifying a very high achievement of the expected competencies.

The UFP, as the goal of study, was interpreted as an objective manifestation of the student's skills achieved in the training process. Here, we highlight the following qualities of the project in its final version (Table 6). The criteria were taken from the official evaluation protocol, but were evaluated qualitatively. 
Table 5. Qualitative characterization of the student's competences according to the levels of Bloom's Taxonomy, as restructured by Anderson (2001) [57].

\begin{tabular}{|c|c|c|c|c|c|c|}
\hline \multirow[t]{2}{*}{ Objectives: Competences } & \multicolumn{6}{|c|}{ Levels of the Bloom's Taxonomy Updated by Anderson (2001) } \\
\hline & 1 & 2 & 3 & 4 & 5 & 6 \\
\hline 1-Acquiring cutting-edge knowledge & $\mathrm{X}$ & $\mathrm{X}$ & & & & \\
\hline 2-Applying knowledge to problem solving & & & $\mathrm{X}$ & & & \\
\hline $\begin{array}{l}\text { 3-Gathering and interpreting data, reflecting and } \\
\text { making judgments }\end{array}$ & $x$ & $X$ & & $x$ & $x$ & \\
\hline 4-Transmitting information & & & & & & $x$ \\
\hline 5-Learning autonomy & & & & & & $\mathrm{X}$ \\
\hline $\begin{array}{l}\text { CT1. Understanding the scientific method. Ability to } \\
\text { analyse synthesis, problem solving }\end{array}$ & & $X$ & $x$ & $x$ & $x$ & \\
\hline $\begin{array}{l}\text { CE8. Analysing and interpreting meteorological, } \\
\text { climatic and hydrological processes }\end{array}$ & & $\mathrm{x}$ & & $x$ & $x$ & \\
\hline $\begin{array}{l}\text { CE11. Handling and applying Geographical } \\
\text { Information System and interpreting remote-sensing } \\
\text { images for environmentalists }\end{array}$ & $x$ & $\mathrm{X}$ & $x$ & & & \\
\hline $\begin{array}{l}\text { CE12. Sample design, data processing and } \\
\text { interpretation of statistical results and statistical } \\
\text { programs and databases }\end{array}$ & $x$ & $x$ & $x$ & $x$ & $x$ & $X$ \\
\hline $\begin{array}{l}\text { CE16. Knowledge and appreciation of data sources and } \\
\text { techniques for territorial analysis for sustainability }\end{array}$ & $x$ & $X$ & & $x$ & $x$ & \\
\hline $\begin{array}{l}\text { CE35. Knowledge and appreciation of city planning } \\
\text { and management }\end{array}$ & & & $X$ & $x$ & $x$ & $X$ \\
\hline $\begin{array}{l}\text { CE36. Knowledge of the processes related to natural } \\
\text { and technological risks and development of mitigation } \\
\text { and risk prevention plans }\end{array}$ & $x$ & $X$ & $X$ & $x$ & $x$ & $x$ \\
\hline
\end{tabular}

Table 6. Qualities of the undergraduate final project (UFP).

\section{Criteria for the Professor}

Necessary time dedicated by the student to the research Collaboration of the professor in the design and planning of the research

Application of the methodology explained by the professor Ability to perform TFG autonomously

Organization of the TFG and the activities to be performed Participation in decision making

Search for information in the appropriate documentary sources

Management of computing resources

Overall result after the preparation of the TFG concerning objectives defined

\section{Qualitative}

Intensely

Highly planned by professor

With great accuracy

Autonomous and creative

Very good

Autonomy and consensus

Wide and rigorous

With great efficiency

All well accomplished

\section{Final Average Score}

\section{A (Excellent)}

Observations of the Professor for the Evaluation Committee

The student's attitude was highly proactive throughout the process, accepting the professor's motivational proposals, maintaining conclusive dialogues with the professor and overcoming the contextual difficulties of the confinement during much of the research period, so the learning climate was very favorable and fruitful.

Source: Own design, inspired by the evaluation protocol of the UFP.

\section{Discussion}

We found that, in general, the results of this work are consistent with the literature. As stated by authors specializing in design research [79]: "In some of these studies, the development of theoretical models is parallel to the design of a product, for example: a set of tasks, a study plan or software for teaching a specific subject. In these cases, the product will be another result of the investigation" [79] (p. 528). In this sense, we have shown the 
entire didactic context and the study prepared for it as a successful part of the research results, since they have made it possible to achieve the objective of student training. This is demonstrated in the preparation of the UFP, which was assessed with the highest rating by a jury. Furthermore, gamification, defined as the application of game elements to the educational field [7], in complying with all of the steps established elsewhere [34], was appropriately designed and successfully executed, as described above. In short, the player has adequately interpreted his role as a researcher interacting with the game, and has achieved the game's goals in simulations that have produced a city model that meets the expected sustainability requirements [8].

At the end of the case study, we found similarities with another work [48], which states that "from the research carried out, it was found that students adjust their learning strategies according to the resources and requirements of the pedagogical proposal undertaken" ( $\mathrm{p} 2$ ). Thus, the student in the present case study improved in terms of autonomy and learning management during the first quarter of the school year to the extent that, by March, the student was able to understand and follow the professor's instructions in an independent manner, using the technological elements of the gamification system with great research skills, generating a sustainable city model and a study of the $\mathrm{NH}$ threatening the city. Furthermore, we agree with the observation made in the previous study [49], that design research analyses "learning in context through the systematic design and study of particular forms of learning, teaching strategies and tools, in a way that is sensitive to systematic nature of learning, teaching and assessment" [49] (p. 76).

Regarding the objectives set for the development of competences by the student in the present case study, the key objective-i.e., the competence in relating research to autonomous learning - was clearly manifested in the questions formulated online to the professor. These reflect the consistency between what was intended as the objective in the study of $\mathrm{NH}$ and the autonomous way of making decisions at key points in the gamification process. The competencies taken as specific objectives were evaluated, very favourably, by means of a protocol in a rubric format based on the requirements of the teaching guide of the UFP material, and based on the conceptualization and development of the research work that was undertaken to prepare the UFP. The communicative competence was evaluated using two elements prepared by the student: (1) the text of the UFP [11], which has an excellent narrative; and (2) the video made for the oral presentation of the UFP before the jury, which has high visual communicative potential. The development of all of the skills in Tables 1 and 2 was demonstrated, both in these two products and in the oral presentation before the evaluation commission supported by the video. Furthermore, a question-and-answer debate was held, which reached a high level of satisfaction among the evaluation commission.

As indicated above, the main subject of this study was the innovative didactic model of scientific-technological training of the final project for an undergraduate student, and this model was delineated and explained in a reproducible way. It has also been indicated that our secondary objective was the production and analysis of teaching tools, such as the CS game described here, which we have adapted to serious play, used, and validated [8]. Since the two objectives are related (one being the result of the other), we conclude that the study of the sustainability of cities and NH by simulation with SC is also a satisfactory result of the objective of innovative university training of this study. For these reasons, we consider that the goals of this study were met, except that, under the restricted interaction of the professor and the student-resulting from the aforementioned state of confinement-there was the consequent lack of certain data on the interactions in the case of study.

The other shortcomings of the study include the lack of definition of certain elements of the action that the professor had to exercise, the need for a more rigorous evaluation of the methodology prepared, and certain deficiencies found in the modelling capacity of the CS game. We plan to continue this work in the future in order to overcome these limitations. Specifically, we intend to apply the model of effectiveness of training with 
improved technology (TETEM) [36] in order to provide new data that offer a broad answer to the question: Is the game more effective than traditional learning methods?

The validity of the results of our study should be considered within the qualitative case-study model, with a single case of interpretive study in which the professor acts as a participating observer. This means that it is not a generalizing quantitative study, but a demonstration of a possible case within a particular context, and in specific material and temporal circumstances. For the subjectivism that might be found in the study, we do not attempt to generalize the results, but rather show that they are possible, and can be replicated in analogous circumstances and contexts, with a similar likelihood of success.

\section{Conclusions}

The analysis of the work undertaken has shown the results to be consistent with the research method adopted, and it reaches a high level as a whole, despite the complexity of the intertwining goals and objectives that are intended for research and teaching. We conclude that this study was successful in its general objective, since it was possible to establish an innovative didactic methodology based on student research, with the use of gamification and simulation with a technological tool. The student participating in the case study proved to be capable of developing scientific and professional competencies at an optimal level. This was demonstrated through the achievement of the general, specific, and transversal competences that constituted the specific objectives. In this sense, the progress made in these specific and transversal competences, which were appropriate to the undergraduate level, through the simulations carried out with the gamification system, were highly satisfactory. Therefore, we conclude that gamification and simulation with Cities: Skylines can improve the university training of environmental experts. Thus, in the three branches of interest of this research-the use of technology, innovation in university teaching, and the development of resources for the understanding and management of natural hazards - new ideas have been contributed, advancing in the Sustainable Development Goal of quality education.

Finally, we summarize the contributions of this work into five topics of great current interest:

1. On the approach to university training: a didactic model that develops the university's learning autonomy and its research competence;

2. On the didactic implementation: the didactic potential of gamification combined with simulation, as a methodology for higher education;

3. On technology: the possibility of turning a game of fun or pleasure into a 'serious game' or tool to achieve scientific and technological competencies in students;

4. On the environment, the knowledge of natural hazards, and their management: the demonstration that these should be studied on models, given their idiosyncrasy, in order to reach competencies of abstraction and modelling, and a global understanding of all of the variables that affect the environment;

5. On the profession of environmentalist: awareness concerning the need to commit to the Sustainable Development Goals (acquiring and improving their professional qualifications) in order to collaborate in the social sustainability and natural resilience of the immediate environment and the world.

It is expected that this work, its direct trajectory, and its continuation contribute new directions in the design of sustainable cities, in the simulation of the control and management of natural hazards, and in the educational challenges that current universities face in order to be sustainable in the future.

Author Contributions: Formal analysis, M.C.-M.; Investigation, P.F. and M.C.-M.; Methodology, P.F; Software, M.C.-M.; Supervision, P.F.; Writing—original draft, P.F. and M.C.-M.; Writing—review and editing, P.F. All authors have read and agreed to the published version of the manuscript.

Funding: This research received no external funding. 
Institutional Review Board Statement: Not applicable.

Informed Consent Statement: Not applicable.

Data Availability Statement: Data presented are original and not inappropriately selected, manipulated, enhanced, or fabricated.

Conflicts of Interest: The authors declare no conflict of interest.

\section{References}

1. Objetivos de Desarrollo Sostenible. Available online: https://www.undp.org/content/undp/es/home/sustainabledevelopment-goals.html (accessed on 14 January 2020).

2. Estudios Medioambientales en la Universidad de Granada UGR. Available online: https://grados.ugr.es/ambientales/pages/ infoacademica/estudios (accessed on 4 April 2020).

3. García, A.S.; Díaz, A.I.; Reche, C.M.P.; Torres, T.J.M.; Rodríguez, R.J.M. Systematic Review of Good Teaching Practices with ICT in Spanish Higher Education. Trends Chall. Sustain. 2019, 11, 7150.

4. Teixes, F. Gamificación: Fundamentos y Aplicaciones, 1st ed.; Universitat Oberta de Catalunya: Barcelona, Spain, 2014; pp. 17-193. ISBN 9788490644850.

5. Flandoli, B.A.M.; Riaño, R.E. El papel de la gamificación en la conciencia ambiental: Una revisión bibliométrica. Rev. Prism. Soc. 2020, 30, 161-185.

6. Barragán, A.J.; Ceada, Y.; Andújar, J.M.; Irigoyen, E.; Gómez, V.; Artaza, F. Una propuesta para la motivación del alumnado de ingeniería mediante técnicas de gamificación. Actas 36 Jornadas de Automática 2015, 710-715.

7. Deterding, S.; Dixon, D.; Khaled, R.; Nacke, L. From Game Design Elements to Gamefulness: Defining Gamification. In Proceedings of the 15th International Academic MindTrek Conference: Envisioning Future Media Environments; MindTrek: New York, NY, USA, 2011; Volume 11, pp. 9-15.

8. Fernández, P.; Moreno, C.M. Urban Sustainability and Natural Hazards Management; Designs Using Simulations. Sustainability 2021, 13, 649. [CrossRef]

9. Fernandez, P.; Ceacero, M. Effects of natural hazards on a sustainable city, design by gamification. In Proceedings of the 11th Global Conference on Business and Social Sciences Series, Bangkok, Thailand, 11-12 December 2020; ISBN 978-967-7-0-8.

10. Ceacero, M. Diseño de Una Ciudad Sostenible y Los Posibles Efectos en ella de Diferentes Riesgos Naturales Mediante Gamificación; Universidad de Granada: Granada, Spain, 2020.

11. Suartama, I.K.; Setyosari, P.; Ulfa, S. Development of an Instructional Design Model for Mobile Blended Learning in Higher Education. Int. J. Emerg. Technol. Learn. 2019, 14, 4-22. [CrossRef]

12. Fernández, P.; Rodríguez, M.C.; Oliveras, F.A. Modelo semipresencial para la formación universitaria. Aplicación a titulaciones técnicas. Enseñanza Ciencias. 2020, 38, 179-197.

13. Marco de Sendai para la Reducción del Riesgo de Desastres 2015-2030. Naciones Unidas. UNISDR/GE/2015-ICLUX ES, 1a edición. 2015, pp. 1-40, Ginebra. Available online: https:/ /www.preventionweb.net/files/43291_spanishsendaiframeworkfordisasterri. pdf (accessed on 7 July 2020).

14. Keller, E.; Blodget, R. Riesgos Naturales: Procesos de la Tierra Como Riesgos, Desastres y Catástrofes, 1st ed.; Pearson Educación: Madrid, Spain, 2007; pp. 2-33. ISBN 978-84-8322-336-9.

15. Gomes, P.J.; Pena, L.A. Urban resilience: A conceptual framework. Sustain. Cities Soc. 2019, 50, $2210-6707$.

16. Tiana, A.S.; Raméntol, V.S.; Morilla, F.M. Implementación de los objetivos de desarrollo sostenible a nivel universitario. Revista Int. Sostenibilidad Educ. Super. 2018, 19, 473-497.

17. Guerra, A. Integration of sustainability in engineering education: Why is PBL an answer? Int. J. Sustain. High. Educ. 2017, 18, 436-454. [CrossRef]

18. Simon, M.; Budke, A. How Geography Textbook Tasks Promote Comparison Competency; An International Analysis. Sustainability 2020, 12, 8344. [CrossRef]

19. Martins, B.; de Castro, V.F. Interações didáticas de domínios curriculares a partir do estudo de caso da Ilha do Fogo (Cabo Verde). RISCOS 21CEGOT Soc. Ensino Geogr. 2016, 401, 788.

20. Nunes, A.N.; Martins, B.; Azeve, M. Exploring the Spatial Perception of Risk in Portugal by Students of Geography. J. Geogr. 2020, 119. [CrossRef]

21. Alam, E. Landslide Hazard Knowledge, Risk Perception and Preparedness in Southeast Bangladesh. Sustainability 2020, $12,6305$. [CrossRef]

22. Teixes, F. Gamificación: Motivar Jugando, 1st ed.; Editorial UOC: Barcelona, Spain, 2015; pp. 79-125. ISBN 9788490649152.

23. Deterding, S.; Sicart, M.; Nacke, L.; O'Hara, K.; Dixon, D. Gamification: Using game-design elements in non-gaming contexts. Proc. CHI EA '11 ACM Press 2011, 2425-2428. [CrossRef]

24. Hueros, D.A.; Domínguez, Y.C.; Godoy, M.Á. Healthy Heart. Developing an app to promote health among young people. Educ. Inf. Technol. 2020, 25, 1837-1854. [CrossRef]

25. Loewen, S.; Crowther, D.; Isbell, D.R.; Kim, K.M.; Maloney, J.; Miller, Z.F.; Rawal, H. Mobile-assisted language learning: A Duolingo case study. ReCALL 2019, 31, 293-311. [CrossRef] 
26. Varnes, D.J. International Association of Engineering Geology. In Landslide Hazard Zonation: A Review of Principles and Practice, 1st ed.; United Nations Educational: Paris, France, 1984; p. 10.

27. Carlson, C.H.; Wong, C.W. If engineers solve problems, why are there still so many problems to solve? Getting beyond technical solutions in the classroom. In Proceedings of the ASEE Annual Conference and Exposition, North Andover, MA, USA; McQuade Library at Merrimack ScholarWorks. 2020; p. 790. Available online: https://scholarworks.merrimack.edu/lib_pub/10/ (accessed on 19 February 2021).

28. Soma, T.; Li, B.; Maclaren, V. Food waste reduction: A test of three consumer awareness interventions. Sustainability 2020, $12,907$. [CrossRef]

29. Lauzurica, D.B.; Salinas, M.D. Computational thinking and robotics: A teaching experience in compulsory secondary education with students with high degree of apathy and demotivation. Sustainability 2019, 11, 18.

30. Valcarce (2017) Gamificando el \#ODS6. Available online: https://www.iagua.es/blogs/alberto-valcarce/gamificando-ods6 (accessed on 9 December 2020).

31. Catedrahidralia (2020) ¡Lanzamos QUODS! Available online: http:/ /17retosods.com/lanzamos-quods (accessed on 9 December 2020).

32. Chisnall, R.; Church, E.; Maurer, A.; Murray, K.; Timmers, K.; Tupy, F.; Volain, N.; Williams, J.; Ziegenfuss, R. El Libro de los ODS (Objetivos de Desarrollo Sostenible); Innovation Lab Schools: Madrid, Spain, 2019.

33. Wu, S.; Wang, J.; Wei, G.; Wei, Y. Research on Construction Engineering Project Risk Assessment with Some 2-Tuple Linguistic Neutrosophic Hamy Mean Operators. Sustainability 2018, 10, 1536. [CrossRef]

34. Maskeliūnas, R.; Kulikajevas, A.; Blažauskas, T.; Damaševičius, R.; Swacha, J. An interactive serious mobile game for supporting the learning of programming in javascript in the context of eco-friendly city management. Computers 2020, 9, 102. [CrossRef]

35. Armstrong, M.B.; Landers, R.N. An Evaluation of Gamified Training: Using Narrative to Improve Reactions and Learning. Simul. Gaming 2017, 48, 513-538. [CrossRef]

36. Landers, R.N.; Armstrong, M.B. Enhancing instructional outcomes with gamification: An empirical test of the TechnologyEnhanced Training Effectiveness Model. Comput. Hum. Behav. 2017, 71, 499-507. [CrossRef]

37. Avedon, E.; Smith, S.B. The Study of Games, 1st ed. 1979. Available online: https:/ /www.amazon.com/Study-Games-Elliott-MAvedon/dp/4871874168 (accessed on 19 February 2021).

38. ¿Qué son las Mecánicas de Juego? Una Aproximación al Concepto. Available online: https://todasgamers.com/author/ lanigromante (accessed on 9 December 2020).

39. Romero, J.M.; Sola, T.; Trujillo, J.M. Instructional Capabilities of Moodle Tools for Production of Courses and Educational Materials. Digit. Educ. Rev. 2015, 28, 59-76.

40. Cañas, J.M.; Martín, M.D.; Arias, P.; Vega, J.; Álvarez, R.D.; Pérez, G.L.; Conde, F.J. Open-source drone programming course for distance engineering education. Electronics 2020, 9, 2163. [CrossRef]

41. Vos, T.E.J.; Fraser, G.; Ortiz, M.I.; Prada, R.; Silva, A.R.; Prasetya, I.S.W.B. Tutorial on a Gamification Toolset for Improving Engagement of Students in Software Engineering Courses. In Proceedings of the IEEE 32nd Conference on Software Engineering Education and Training, CSEE and T, Munich, Germany, 9-12 November 2020.

42. De la Cruz, M.K.B.; Tolentino, A.N.; Roleda, L.S. Increasing Student Motivation in College Physics with Gamified Instruction. Proc. ACM Int. Conf. Proc. Series 2020, 268-274. [CrossRef]

43. Legaki, N.Z.; Xi, N.; Hamari, J.; Karpouzis, K.; Assimakopoulos, V. The effect of challenge-based gamification on learning: An experiment in the context of statistics education. Int. J. Hum. Comput. Stud. 2020, 144, 2496. [CrossRef] [PubMed]

44. Costa, F.A.; Viana, J.; Raleiras, M. What do higher education students have to say about gamification? Adv. Intell. Syst. Comput. 2021, 1236, 56-65.

45. Confrey, J. The evolution of design studies as methodology. In The Cambridge Handbook of the Learning Sciences, 1st ed.; Sawyer, R.K., Ed.; Cambridge University Press: New York, NY, USA, 2006; pp. 135-152. ISBN 978-0521607773.

46. Kelly, A.E.; Baek, J.Y.; Lesh, R.A.; Rit $\neg$ land, B.B. Enabling innovations in education and systematizing their impact. In Handbook of Design Research in Methods in Education. Innovations in Science, Technology, Engineering, and Mathematics Learning and Teaching, 1st ed.; Kelly, A.E., Lesh, R.A., Baek, J.Y., Eds.; Routledge: New York, NY, USA, 2008; pp. 3-18. ISBN 9781315759593.

47. Gibelli, T. La investigación basada en diseño para el estudio de una innovación en educación superior que promueve la autorregulación del aprendizaje utilizando TIC. In Proceedings of the Congreso Iberoamericano de Ciencia, Tecnología, Innovación y Educación, Buenos Aires, Argentina, 12-14 November 2014; pp. 12-14.

48. Molina, M.; Castro, E.; Molina, J.L.; Castro, E. Un acercamiento a la investigación de diseño a través de los experimentos de enseñanza. Enseñanza Cienc. 2011, 29, 075-088.

49. De Benito, B.; Salinas, J.M. La investigación Basada en Diseño en Tecnología Educativa. Rev. Interuniv. Investig. Tecnol. Educ. (RIITE) 2016, 44-59. [CrossRef]

50. Richey, R.C.; Klein, J.D.; y Nelson, W. Developmental research: Studies of instructional design and development. In Handbook of Research for Educational Communications and Technology, 2nd ed.; Jonassen, D., Ed.; Lawrence Erlbaum Associates: Mahwah, NJ, USA, 2004; pp. 1099-1130.

51. Plomp, T. Educational Design Research: An Introduction. In Tjeerd Plomp y Nienke Nieveen, An Introduction to Educational Design Research Proceedings of the Seminar Conducted at the East China; Normal University: Shanghai, China, 2010. 
52. Guia docente de la asignatura Trabajo de Fin de Grado. Available online: https://grados.ugr.es/ambientales/pages/ infoacademica/guiadocentetfgccaa_2019_2020 (accessed on 29 July 2020).

53. Werbach, K.; Hunter, D. Gamificación Revoluciona tu Negocio con las Técnicas de los Juegos, 2nd ed.; Pearson Educación: Madrid, Spain, 2014; pp. 89-106. ISBN 978-84-944171-6-0.

54. Bloom, B.S.; Engelhart, M.D.; Furst, E.J.; Hill, W.H.; Krathwohl, D.R. Taxonomy of educational objectives: The classification of educational goals. In Handbook I: Cognitive Domain; David McKay Company: New York, NY, USA, 1956.

55. Morshead, R.W. On Taxonomy of educational objectives Handbook II: Affective domain. Stud. Philos. Educ. 1965, 4, 164-170. [CrossRef]

56. Anderson, L.W.; Krathwohl, D.R. A Taxonomy for Learning, Teaching, and Assessing: A Revision of Bloom's Taxonomy of Educational Objectives; Longman: New York, NY, USA, 2001; ISBN 978-0-8013-1903-7.

57. Armstrong, P. Bloom's Taxonomy. In Vanderbilt University Center for Teaching; Vanderbilt University: Nashville, TN, USA, 2010.

58. Keene, J.; Colvin, J.; Sissons, J. Mapping student information literacy activity against Bloom's taxonomy of cognitive skills. J. Inf. Lit. 2010, 4, 6-21. [CrossRef]

59. Our Googley Advice to Students: Major in Learning. Available online: http:/ /googleblog.blogspot.com/2008/07/our-googleyadvice-to-students-major-in.html (accessed on 14 May 2020).

60. Bloom's Digital Taxonomy. Available online: https://edorigami.edublogs.org/blooms-digital-taxonomy (accessed on 6 July 2020).

61. Maslow, A.H. Motivation and Personality; Harper: New York, NY, USA, 1954.

62. Herzberg, F.; Mausner, B.; y Snyderman, B. The Motivation to Work; John Wiley and Sons: New York, NY, USA, 1967.

63. McClelland, D. Estudio de la Motivación Humana; Nárcea: Madrid, Spain, 1989.

64. Vroom, V. Work and Motivation; John Wiley and Sons: New York, NY, USA, 1964.

65. Porter, L.W.; Lawler, E.E., III. Manage-Rial Attitudes and Performance; Irwin-Dorsey: Homewood, IL, USA, 1968.

66. Locke, E.A. Purpose without consciousness: A contradiction. Psychol. Rep. 1969, 25, 991-1009. [CrossRef]

67. Csikszentmihalyi, M. Beyond Boredom and Anxiety; Jossey-Bass: San Francisco, CA, USA, 1975.

68. Valera, J. Gamificación: 6 Teorías de Motivación en Juego. Available online: https://www.menteposible.com/2012/05/15 / gamificacion-6-teorias-de-motivacion-en-juego (accessed on 8 December 2019).

69. Joyce, B.; Weil, M. Modelos de Enseñanza; Anaya: Madrid, Spain, 1985.

70. Putra, E.; Tantular, B.A.; Ruhimat, M. The Effect of Simcity as Instructional Media in Geography Learning on Learners' Spatial Intelligence. In Proceedings of the 2020 International Conference on Education Development and Studies ACM International Conference Proceeding Series, Paris, France, 29 March 2020; pp. 6-9.

71. Pramaputri, N.I.; Gamal, A. Urban Planning Simulation Game and the Development of Spatial Competence. IOP Conf. Ser. Earth Environ. Sci. 2019, 396, 012016. [CrossRef]

72. Watson, Z.; Zaidi, S.F.M. Understanding positive impact of game interactivity in education. ACM Int. Conf. Proc. Ser. 2019, 118-123. [CrossRef]

73. Arnold, U.; Söbke, H.; Reichelt, M. Simcity in infrastructure management education. Educ. Sci. 2019, 9, 209. [CrossRef]

74. Sukhov, A. Ethical issues of simulation video games. Proc. Eur. Conf. Games Based Learn. 2019, 705-712.

75. Haahtela, P.; Vuorinen, T.; Kontturi, A.; Silfvast, H.; Väisänen, M.; Onali, J. Gamification of Education: Cities Skylines as an educational tool for real estate and land use planning studies. Game Urban Plan. Aalto Sch. Eng. 2015, 2015, 13.

76. Pinos, J.; Vozenilek, V.; Pavlis, O. Automatic geodata processing methods for real-world city visualizations in cities: Skylines. ISPRS Int. J. Geo-Inf. 2019, 9, 17. [CrossRef]

77. Poulsen, M.; Køber, E. The Game IT Handbook. Ingerslev, T., Ed.; Available online: www.projectgameit.eu (accessed on 9 March 2020).

78. Serradell, E. El uso de los juegos y simuladores de negocio en un entorno docente. Oikonomics 2014, 1, 86-92. [CrossRef]

79. Hjalmarson, M.A.; y Lesh, R. Design research. Engineering, systems, products, and processes for innovation. In Handbook of International Research in Mathematics Education; Routledge: London, UK, 2008; pp. 520-534. 